\title{
"If I choose history it is likely that I won't be able to leave for the cities to get a job": Rural learners and the choosing of history as a subject
}

\section{Johan Wassermann}

Honorary Professor, Social Sciences Education Cluster, School of Education, University of KwaZulu-Natal, Pinetown, South Africa

Johanwassermann@gmail.com

https://orcid.org/0000-0001-9173-0372

\section{Marshall Maposa}

Social Sciences Education Cluster, School of Education, University of KwaZulu-Natal, Pinetown, South Africa Maposam2@ukzn.ac.za

https://orchid.org/0000-0001-9264-2569

\section{Daniel Mhlongo ${ }^{1}$}

Social Sciences Education Cluster, School of Education, University of KwaZulu-Natal, Pinetown, South Africa

(Received: 17 May 2018; accepted: 9 October 2018)

\section{Abstract}

In this paper we aim to understand and explain why rural learners in a South African school did not choose history as a school subject in Grade 10. Using a pen-and-paper test and focus group interviews we probed the views of 15-year-old rural learners who did not choose history. What the data revealed was that mathematics, physical science, and commercial subjects, rather than history were favoured. The reasons for this centred on taking subjects that were viewed as leading potentially to decent jobs or funding to study and therefore being advantageous to the future prospects of the learners in an urban setting. This mind-set was reinforced by teachers, parents, older siblings, the state, and the formal economy. In the process, history was seen to be the preserve of learners who could not cope with mathematics, physical science, and commercial subjects and were therefore not worthy of urbanisation and upward mobility. In short, studying history was equated with negative notions of rurality and choosing to study it was seen as likely to result in not making it to the better life that cities offered. However, with some irony, studying history was seen to be an urban endeavour which implied that at some time in the future, once the learners were urbanised and economically better off, the subject could possibly be studied again.

Keywords: rurality, history, democracy, city, urban, sustainable education away shortly after completing his studies. 


\section{Introduction}

All three of us are history teachers and we are all products of diverse rural learning ecologies straddling two African countries. One of the shared educational aspects of our rural education was the omnipresence of history as a school subject. The impact of history on us was such that we made a living out of it. However, in post-apartheid South Africa, history as a school subject has seemingly fallen on hard times and pessimism seems to have enveloped the discipline. Much of this related to the decline in the number of learners taking history as a subject up to Grade 12. Many reasons have been proposed for this, ranging from the introduction of Outcomes Based Education which seemingly rendered history impractical (Dube, 2018), to the subject being viewed as merely about memorising contentious content (Meyer, Blignaut, Braz, \& Bunt, 2008). In the process it seems that former white and rural schools, especially, were shedding the subject. The available statistics from 2004 to 2010, although somewhat dated, seem to support the idea of history being a subject in decline. Accordingly, in seven of the nine provinces the number of learners taking history in Grade 10 declined. The sharpest decline for the period 2004 to 2010 was in Mpumalanga where an estimated 82\% fewer learners took history in Grade 10 in 2010 when compared to 2004. In both the Eastern Cape and KwaZulu-Natal, the number of history learners declined by an estimated $31 \%$ during the same period (van Eeden, 2012). The statistics, as well as the range of views related to the decline of history as a school subject, pricked our curiosity and we started to wonder how this relates to the general status of history as part of schooling, especially in rural areas similar to those where we studied the subject as learners.

In light of the above, we embarked on a research project to come to some understanding of how learners in a rural context end up not choosing history as a subject at the end of their Grade 9 year. A constant key point of departure was that we wanted to hear the voices of the learners on the factors and processes involved in not choosing history as a subject. To us that was the gap in the existing knowledge - a lack of understanding of how learners in a rural context went about choosing or not choosing history as a subject to study beyond Grade 9. In the process we set about tapping into the relationship between experiences of rurality and the personal future ambitions of learners roughly 15 years of age in relation to history as a subject. In so doing we hoped to provide a snapshot of the competing agendas when subjects in general, and history specifically, are considered for future study. Finally, we also hoped that the study would reveal some insights from the perspective of learners about history and its relation to schooling.

\section{Literature Review}

Much has been written about the nature of history at school level in relation to its intellectual and disciplinary functions. One of the clearest articulations in this regard is by Kukard (2017) who argued that, in terms of history at school, three broad orientations are possible. The first of these is memory history which promotes an academic identity that emphasises the chronology of historical events since it relates generally to politics, the formation of the nation-state, and the role of leaders and so-called big historical personalities in this formation. 
Much emphasis is placed, as part of a national narrative, on the memorisation and logical organisation of facts. In terms of a civil identity learners are expected to know the national story and to develop a nationalist sense of patriotism and pride.

The second orientation is analytical history. In terms of an academic identity accent is placed on procedural historical thinking concepts such as change and continuity, cause and consequence, and multi-perspectivity. In analytical history emphasis is placed on the disciplinary nature of the subject and, based on the available historical evidence, that more than one interpretation is possible. An overarching national narrative is shunned in favour of historical themes, turning points, and the fact that some interpretations are more likely than others. In terms of a civil identity analytical history focuses on historical and critical thinking skills, the fact that different perspectives exist, and that the accuracy of historical narratives should be challenged (Kukard, 2017).

The third orientation identified by Kukard (2017) is critical history. As far as an academic identity is concerned, the emphasis falls on substantive knowledge that relates to ordinary people and marginalised groups in society. In critical history leaders feature only insofar as their actions have impacted on society as a whole. Ideas that are foregrounded in this kind of history include social justice, human rights, and freedom. These are foregrounded with the aim of preparing learners to understand and engage with contemporary local and global issues. In the process, historical evidence is studied by focusing on prejudice and control. In terms of a civil identity learners are educated to understand personal values and how they relate to contemporary society. The overall aim of critical history is for learners to grasp the relationship between the past and the present and to engage, as active citizens, in a democratic manner with social, political, and economic issues.

Kukard's (2017) orientations related to the intellectual and disciplinary functions of history at school level must not be seen to be watertight compartments since fluidity permeates the three orientations. For example, as argued by Kukard, the current Curriculum Assessment Policy Standard (CAPS) for history is located in analytical history while embracing elements of critical history. The disciplinary orientations and how they speak to historical thinking, as theorised by Kukard, must be understood in the context of values and uses attributed to history at school level. It has been purported that the societal and civic functions of history include developing in learners a historical consciousness to enable understanding of the relationship between the past, the present, and the future (Southgate, 2000); helping in the creation of national identities (Carrier, 2002); making for good citizenship (Stearns, 1998); promoting human values and moral understanding (van der Leeuw-Roord, 1997); aiding learners in becoming socially literate (Mackie, 2004; Meyer et al., 2008); and helping develop generic skills related to interpretation, judgement, and critical thinking (VanSledright (2011). It is also useful in the place of work (Stearns, 1998). However, Peter Lee (1998) pours cold water on the idea that the teaching of history at school level promises everlasting societal and civic outcomes. In his view teaching history "cannot guarantee democrats, patriots, or even anti-racists, because the past is complex and does not sanctify any particular or personal position above another" (pp. 52-54). 
The sparse literature dealing with why learners view choosing history negatively provides a nuanced look at the subject. First and foremost, history is viewed as irrelevant, boring, and unimportant. History, unlike certain other subjects, is also seen as adding limited benefit to learners' lives and is unable to provide them with employment opportunities (Bycina, 2012; Hannon, 2012; Joseph, 2011; Steen, 2012). Additionally, learners argued that understanding history as a body of knowledge is difficult so they chose to avoid it (Haydn, 2011; Joseph, 2011). Learners also reasoned that studying history brought about painful memories and ideas of revenge. Since this is not what they want in their lives the subject is not chosen (Joseph, 2011; Mackie, 2004). Finally, Haydn (2011) argued that the personality and temperament of the history teacher, and his/her general interaction with learners in relation to history as an abstract body of knowledge, also has the potential to turn learners against the subject.

\section{Research Methodology}

Rural contexts and settings cannot, in a reductionist manner, be viewed as being uniformly similar and it is therefore necessary to contextualise the rural area in which our research took place. The study was conducted in three schools in the Mtubatuba district of KwaZulu-Natal, South Africa. Colloquially, the area in which Mtubatuba is situated is still referred to as Zululand. Much of this area formed part of the KwaZulu Bantustan during the apartheid era. Currently the area falls under the UMkhanyakude Educational District. According to the available data only 64\% of the learners in this district passed matric in 2018 (Mngadi, 2018). The learners who participated in the study were educated in schools categorised as Quintiles 1,2 , and 3, namely poor no-fee-paying schools. In total $97 \%$ of the schools in this area fell into these categories (Department of Basic Education, 2016. The area has also had its fair share of political tension between the African National Congress (ANC) and the Inkatha Freedom Party (IFP) in the past. In short, politics and poverty (see Mbokazi \& Bhengu, 2008) are a key part of the social context of the rural area in which the research took place. We conducted our research in School A, situated in the predominantly IFP stronghold of Emanzamnandi, School B, situated in the largely ANC dominated Enkundusi area, and School C, located in the Endombeni area, where residents had allegiance to both the ANC and IFP. ${ }^{2}$

Following Patton (1990), who referred to the selection of purposively selected research sites as "Criterion Based Purposive Sampling (p. 69) we purposively selected three schools as sites for our study because they are located in the same rural context, and all offered history as a subject up to Grade 12. Making a sampling choice in this manner is supported by Rule and John (2011) who posited that research sites and participants can be deliberately selected if their suitability will advance the aims of the study. In our case, we deemed that such purposive sampling would do exactly that. In addition to these reasons, one of the researchers was familiar with the schools.

Following the ethical clearance policy of the University of KwaZulu-Natal, pseudonyms are used throughout to ensure the confidentiality of both institutions and individuals. The ethical clearance number allocated by our institution to this study is HSS/0670/011M. 
Access to the three schools as research sites was anything but straightforward and took some negotiating with the principals, management teams, and parents. One of the fears harboured was that we were outsiders with political agendas who came to disrupt learning or educational inspectors from head office. Consequently, deputy principals at each of the three schools were tasked with producing a group of Grade 10 learners who chose not to study history, an equal number of boys and girls, to participate in the first part of our research. Given the context in which the research took place, all the learners were black.

The initial data for this study was generated by means of a pen-and-paper test open-ended survey that consisted of a single open question printed at the top of an A4 page to allow ample room for the learners to respond. The question read: "Why did you not choose history as a subject in Grade 10?" To assist the learners an isiZulu translation of the question appeared directly beneath the English one. The participants were given 45 minutes during class time, kindly set aside by the schools involved, to complete the survey in a written format and language with which they were comfortable. Allocating enough time to complete the survey and allowing the learners to answer in the language of their choice served to enhance the trustworthiness of the data.

The rationale for using a pen-and-paper test was to allow the learners the opportunity to share the reasons behind their choices in an uninhibited, unconstrained, and reflective manner. At the same time, we hoped that the anonymity of an open-ended survey would serve to yield rich data. In the view of Delport and Roestenburg (2010), "open questions permit adequate answers to complex issues; allow participants to answer in detail and to qualify and clarify responses; make space for unanticipated findings to be discovered and permit creativity, selfexpression and richness of detail" (p. 174). The data generated by the open-ended survey was translated into a single English language document and then analysed by means of open coding. Following Delport and Roestenburg (2010), the data was broken down line-by-line, examined, compared, conceptualised, and categorised. Once the data was turned into manageable chunks, codes that served to anchor the key points of the data were allocated. Next, codes of similar content were grouped together to form themes. This process was repeated until a point of saturation was reached.

The pen-and-paper test was followed by focus group interviews. Compared to how the openended survey had to be conducted, we were allowed greater liberty by the schools in selecting the focus groups. At each school a focus group of roughly ten learners each, generally five boys and five girls, based on their willingness to participate in such an exercise, was created. Post-survey focus groups were deemed useful for they helped the learners to suggest dimensions and nuances not originally thought of, some of which were sparked by the group interaction, and enabled us to verify and probe the responses gleaned from the survey (see Taylor-Powell \& Renner, 2003). The focus group interviews were conducted in isiZulu, audiotaped, transcribed verbatim, translated into English, and then analysed by the same open coding means as was the pen-and-paper test.

The sets of data obtained from the open-ended survey and the focus group interviews were then brought into conversation and the themes that emerged allowed for a nuanced 
understanding of the relationship between rurality, personal aspirations, and not choosing history as a subject in Grade 10.

\section{Data analysis}

We have chosen to present the findings of the research process in a narrative fashion so as to give voice to the rural learners who participated in this study on why they did not choose history as a subject for Grade 10.

What emerged as the major post-school priority of the research participants was to secure employment in the city. In their view choosing to study history in Grade 10 would not aid them in this regard. Support for this was overwhelming and two learner voices in this regard will suffice: "I did not choose history because it cannot provide me with a suitable job" and "If you choose history there is scarcity of jobs like being a lawyer, policemen and a nurse." This was then linked to the geographical context of the learners and it was argued that if you choose history as a subject you "won't be able to leave for the cities to get a job." The vast majority of learners who participated in this study had a clear vision of what would happen in the future if history were to be chosen; they would be tied to their rural area forever and with little prospect of decent employment. Instead, they argued, they would end up as "ordinary clerks" or do gardening, work as labourers on sugarcane plantations, or do babysitting as nannies and maids. One learner captured this future clearly: "I feel if I choose history, I will be adding numbers on the unemployed South Africans as a result I chose commerce."

In light of the above the learners claimed that most former learners they knew who had completed Grade 12 with history as a subject, were not working, at least not in "decent jobs." The reason proposed for this was that the knowledge history offered was irrelevant in securing employment in a technologically oriented commercial world. To the participants the answer was simple: the context in which they found themselves required people with knowledge of mathematics, physical science, and commercial subjects because "technology and science are the cornerstones of life." As a result, learners linked their future career prospects to the study of these subjects at school. This choice was, in turn, linked to youthful ambitions: "I feel if I choose commercial subjects, I am likely to be exposed to business ventures which might help me to start my own business."

What became abundantly clear was that the participants saw a correlation between choosing history as a subject and being economically trapped in a rural setting doing mundane or dangerous jobs. Support for such thinking came in the form of statements such as the following: "If I choose history, I'm likely to be a politician a job that might endanger my safety during political parties' inter-wars" and "I did not choose history because I was afraid of contested nature of rural politics." These comments must be seen against the backdrop of the research context as outlined above. What this points to is that history, although not commercially viable in a rural context, is viewed as being powerful enough to get learners involved in politics. However, an alternative but related perspective on politics and historical knowledge was also revealed by the data. One learner argued that "history has lost its value 
because we now have freedom and we are all united, black and white and above all our main aim now is to secure a job to feed our family as there is poverty in rural areas." In sum, the political value the subject had has run its course and seeking economic well-being is now paramount.

What the analysis of the data also revealed was that the poverty and deprivation experienced in their rural area pushed learners away from history as a subject. One respondent explained, "Poverty in rural areas makes us choose science and commerce because we are looking for bursaries that will help us in our future careers." The choice not to take history was also motivated by what learners experienced economically at home. As one respondent said, "The financial standings of my family is appalling as a result I cannot choose history because it won't change my family financial standing." What the learners made clear was that, in their deprived rural context, they need money for their daily necessities and choosing history would not lead to this. A comment of one of the learners captured this sentiment cuttingly, "I'm coming from poor family therefore I chose subjects that will draw me closer to money."

One of the ways in which the learners could fulfil their economic needs was by securing money to study after leaving school. Choosing history was viewed as being detrimental to such ambitions. The logic of the arguments offered in this regard generally ran like this: "If I do commerce I feel after completing matric I can get a casual employment until I can secure money to go to the university." History was thus viewed as a stumbling block to securing financial aid or bursaries. As one learner said, "We choose subjects that are known to be financed by companies and institutions of higher education." A groundswell of support for this kind of thinking emerged from the data: "If you do history you do not get sponsors to further your studies" and "I did not choose history because there are no bursaries."

In contrast, the view was expressed that similar constraints did not exist when learners chose physical science, mathematics, and commercial subjects since financial institutions were seen to be willing to aid university studies in these fields. This was presented as a major attraction to participants whose families could not fund their tertiary studies. The media and television played a key role in shaping such thinking; a learner explained, "In all media adverts they advertise about sponsors for science and commerce." Additionally, the history learners also pointed out that in their view NGOs offer help only to science learners which left history learners feeling demotivated. What was thus clear in the minds of the research participants was that choosing history as a subject will hinder them from securing funding for any tertiary studies at institutions invariably located in urban areas. Their thinking also revealed a powerful but erroneous belief that no funding at all exists for studying history.

In summary, the view held by the participants was that choosing to do history in Grade 10 was not suitable for rural learners since they must choose subjects that might bring in funding to study and/or that might lead to prospects. In contrast, it was argued, that "urban parents are not desperate for money like rural parents." This utopian thinking about cities was supported by views such as: "Learners' parents in cities are not poor maybe they can choose history because they do not need money from sponsors as we do in rural areas." Furthermore, the thought was expressed that history was irrelevant to rural learners because "history is for 
learners who stay in cities where there are research opportunities." Not only was history dismissed by some of the rural learners as a subject for urban learners and not for them since their parents are unemployed and poor but it was also given a racial tint by the claims such as: "Whites, Coloureds and Indians can study history because they do not need bursaries after matric" because their parents have money and they reside in cities. It is thus clear that a sentiment existed among the rural learners that history has value but this value was only for those in more advantaged settings.

Consequently, participants stated time and again, "History means nothing to us in rural areas and our future plans to assist us to move out of rurality" and "I did not choose history because it was going to trap me in rurality and not help me escape rural life to the cities." In the view of these learners getting to the city all depended on which subject they selected, therefore, as one learner explained, "I chose science with the hope that I will be able to go to better places like Durban."

What the data further revealed was that in their views towards choosing history the learners were influenced not only by the socioeconomic conditions in which they found themselves but also by teachers, peers, and family members. Teachers, as powerful and influential figures close to the learners, emerged as significant role players in discouraging learners from studying history after Grade 9. As one learner explained, "Most of us in our school were not given the opportunity to choose but we were told what to choose." Consequently, learners were put into difficult situations; one of them claimed, "I did not choose history because I was afraid to oppose my class teacher who told me not to choose history." Other teachers were more subtle in this regard and played on the emotions of the learners, as one of them revealed, "In my school teachers always say if we want bright future we should not choose history." The learners admitted that they did not question the truth of such claims and accepted them as statements made by figures of authority.

In the process of actively discouraging certain learners from choosing history, teachers also directed other learners towards the subject. A learner explained, "Teachers in my school themselves channel all poor performers to history." It is thus not surprising that one learner explained that "in my school failures choose history." Learners who were deemed as having no hope of success in mathematics, physical science, and commercial subjects were thus purposefully guided towards taking history. Unsurprisingly, these gave credence to the perception among the research participants that learners who did not choose history were better and bound for a successful life in the city when compared to those routed towards history who are doomed to remain trapped in a deficient rural context.

The power of teachers as socialising agents and figures of authority in furthering the negative stereotypes attributed to learners doing history seems to have been part of the culture of all three schools. Unsurprisingly, then, a learner from School A admitted, "In my school history learners are looked down upon by other learners" while another commented that "if you study history you are always a laughing stock." In School C it was no different. A learner said, "I did not choose history because in my school history class is known as underachievers' class." The resulting peer pressure proved to be telling and learners who had considered choosing 
history acknowledged avoiding it. As one participant said, "I do not want to be undermined by other learners that is why I cannot choose history." The labels attached to learners who chose history, by teachers and non-history-taking learners alike, became an important factor in discouraging learners from pursuing the subject. Evidence for this can be found in a learner's words: "People were always telling me that a learner doing history is stupid." As a result, only certain alternatives remained as of the participants explained, "At a younger age I wanted to study history, but my friends advised me not to choose it then I chose science." Teachers and those learners who chose not to take history therefore combined in an uncoordinated manner to create a negative mind-set about history as a subject. This had a serious impact on impressionable teenagers who, in many cases, wanted to please and conform; they could achieve both by not choosing history. However, when pressed during the focus group interviews the learners failed to provide convincing reasons about their believing in the stereotype they held of history learners. Instead, they explained that they were told so by their friends, parents, and teachers.

Parents and other family members also influenced learners not to choose history in Grade 9. This was openly admitted by some of the respondents during the focus group sessions. One said, "I chose science because my parents did not want me to choose history" and another explained, "I did not choose history because I felt my parents were going to be hurt." These choices were again linked to their rural economic context. For one participant, "In my home my parents rely on my education that, when I work, I will get a decent job as a result I chose science." Other family members also exercised an influence on the rural learners. A learner explained, "I was influenced by my elder brother not to choose history if I wanted to have a decent job in the future." Scant wonder, then, that one participating learner exclaimed, "I would like to see teachers and parents not interfering with learner's right of choosing."

\section{Discussion}

A complex and ambiguous narrative emerged from the data on the factors and processes at play when 15-year-old Grade 9 learners in a rural setting had to decide whether they wanted to continue studying history. Foremost was the powerfully constructed idea that choosing history would mean being trapped in a backward and inhibiting rural setting. Additionally, choosing history would mean being bound to undesirable occupations in the self-same rural context, except if one wanted to dabble in the dangerous world of politics as a career. On top of this it was argued that it would be very difficult to secure funding for further studies. Choosing history in Grade 9 would, in the view of the research participants, mean binding themselves to a rural lifestyle already being lived by many of their families and from which they wanted to escape by moving to the city. And escaping to the city seems to be worth it. Visagie and Turok (2017) argued that in South Africa, between 2008 and 2014, close on 400,000 people were lifted out of poverty after moving from rural areas to cities. Not only were their poverty levels halved but their unemployment levels fell.

The above narratives were powerfully propagated by many of the adults involved in the lives of the learners who participated in this study. Teachers, parents, and older siblings, possibly 
based on their own lived experiences, strongly encouraged learners not to do history beyond Grade 9. The broad reasoning was that it would not allow them to get ahead in life, a metaphor for finding a job or a funded study opportunity in the city. Support for this thinking comes from the emerging work of Langa (2018) on African parents' attitude to their children taking history; they strongly discourage their offspring to take the subject because it is viewed as inhibiting in a post-apartheid world that offers many opportunities.

The discouragement by adults went hand-in-hand with the streaming of learners by schools in Grade 10. Those who were viewed as able found themselves taking mathematics, physical science, and commercial subjects, and those who were not were channelled towards taking history. Seemingly, this meant that it was fine for learners streamed into history and labelled and othered in the process, to remain trapped in a rural setting. However, the affinity for mathematics, physical science, and commercial subjects must also be understood against the very authoritative message constructed around the importance of these subjects by the state, the media, the formal economy, and other role players. Messages like this become even more influential when we consider the context of dire poverty in which the learners who participated in this study find themselves. Taking mathematics and science was seen consequently as the route to follow to achieve success, as reported elsewhere (see HSRC \& EPC, 2005).

What is clear is that mathematics, physical science, and commercial subjects were elevated to a special status by the rural community in which this study took place. In the process, studying these subjects took on a mythical truth of its own that learners will gain not only status by studying these subjects (HSRC \& EPC, 2005) but get jobs and opportunities to study and, in so doing, escape their oppressive rural context (Langa, 2018). This powerful construction is but partially true since studying mathematics, physical science, and commercial subjects offers no guarantee of jobs, funding, or bursaries and no miracle cure for the woes experienced by the learners in their rural setting. Securing jobs and especially student funding are in reality part of a far more challenging and complex business (Motala, 2017) than merely not studying history up to Grade 12 . However, choosing history was seen as "selecting a stumbling block" and therefore, generally speaking, history was viewed as a subject of limited value and little use. As a result, in a district close to our research area most high schools have phased history out (Dube, 2018).

The above speaks to the fact that parents, learners, and teachers have a limited understanding of the intellectual, disciplinary, societal, or civic functions of history as a subject (Subbiah, 2018). Much of this is probably rooted in the persistence of teaching memory history in the area in which the research took place (Dube, 2018) even though CAPS has framed the subject as a discipline that expects learners to engage analytically with the subject (Kukard, 2017). Equally, history, clearly, is not taught as a relationship between the past and the present and is not presented as having to do with how active citizens can, in a democratic manner, engage with social, political, and economic issues (Kukard, 2017). Such a conceptualisation of history would have allowed learners to bring some understanding to their context. By adopting such a strong stance against choosing history in Grade 10 learners are denied the 
opportunity to engage with a body of knowledge as valuable as that offered by mathematics, physical science, and commercial subjects to make sense of the world they inhabit.

But it is not as if the learners who did not choose history viewed the subject as completely without use. However, the research participants regarded the value of the subject to be located elsewhere-in the past when the liberation struggle took place or in an affluent urban context where parents are believed to have money. It was argued that where no real economic needs existed, learners could indulge in the study of the subject, but in the rural context in which these learners found themselves, history would be a luxury.

What also became clear was that limited interest existed among the participating learners in engaging with or resolving the issues their rural area faced. To them the positives attributed to rurality such as innovation and resilience (Moletsane, 2012) were not visible. As a result, a conscious decision was made not to engage with history from Grades 10 to12 and, in so doing, they avoided developing an understanding of why, historically speaking, certain rural areas, including the one in which the research population resided, are the way they are. Instead, history was equated with rurality and vice versa and this meant stagnation and backwardness, and therefore everything that mathematics, physical science, and commercial subjects and cities were not.

Overall, it can be concluded that the learners who participated in this study longed for a schooling that was utilitarian in nature. Such schooling should serve to alleviate the challenging economic conditions they and their families face. It must also be an education that can bring economic advancement by preparing learners for "decent jobs" and opportunities to study further in the city. In this view of schooling, history would not have a place, except if it could, in a utilitarian manner, improve the economic plight of rural learners.

\section{Conclusion}

Why do teenagers, roughly 15 years of age, in the rural setting in which they find themselves view the choosing of history in Grade 10 as being detrimental to their future prospects? Proposing possible answers to this question is filled with both complexity and ambiguity. What is clear is that mathematics, physical science, and commercial subjects were powerfully linked by the learners to economic prosperity, study opportunities, and migration to the city. This mind-set is supported by powerful role-players on both the macro level of the state and the formal economy and on the micro level of teachers, peers, and family members of the learners who participated in this study. Taking history as a subject was frowned upon and the intellectual, disciplinary, societal, and civic value it offers was seen to be being linked to the negative aspects of rurality which will serve merely to chain learners to their rural setting. Consequently, history was reserved for those deemed not good enough to do mathematics, physical science, and commercial subjects and therefore not worthy of economic prosperity and migration to the city. 
What is thus clear is that history is no longer the omnipresent subject in rural areas as it was when we, the authors, were learners. Furthermore, against the backdrop as outlined above, history will in all probability continue to lose ground in rural areas and the numbers of learners taking it will continue to decline. The reasons for this revolve around experiences of rurality, the personal future ambitions of learners, and the envisaged kind of schooling that speaks to their ambitions. In sum, taking history was viewed as reinforcing negative ideas of rurality and did not speak to the utilitarian schooling the learners, and the adults in their lives, valued. Considering how such a mind-set has been internalised we are unsure if the status of history in rural areas can be turned around. Making history compulsory up to Grade 12, as proposed by the Ministerial Task Team (2018) would therefore be a challenging undertaking in rural areas such as the one in which our research took place.

However, if there is a ray of hope it is in the fact that once they are urbanised, as alluded to by the research participants, things might change. Evidence for this is the fact that learners taking history in Gauteng, South Africa's only urban province, increased by 21 per cent between 2004 and 2010 (van Eeden, 2012). This could mean possibly that the self-same learners who shunned the subject in their rural context might end up studying it under better economic conditions in the city.

\section{References}

Bycina, A. (2012, April 3). Is history an important subject in school? Or should we be focussing on the future? [Online forum comment]. Retrieved from TED website: https://www.ted.com/conversations/10377/is_history_an_important_subjec.html

Carrier, R. C. (2002). The function of the historian in society. The history teacher, 35(4), 1-6.

Delport, C. S. L., \& Roestenburg, W. J. H. (2010). Quantitative data collection methods. In A. S. de Vos, H. Strydom, C. B. Fouche, \& C. S. L. Delport (Eds.), Research at grass roots for the social sciences and the human services professions (pp. 171-205). Pretoria, RSA: van Schaik.

Department of Basic Education. (2016). Education statistics in South Africa 2015. Pretoria, RSA: Department of Basic Education.

Dube, C. M. (2018). The views of selected South African history teachers on school history as specialised subject knowledge (Unpublished doctoral dissertation). University of KwaZulu-Natal, South Africa.

Hannon, S. (2012, April 2). Is history an important subject in school? Or should we be focussing on the future? [Online forum comment]. Retrieved from TED website: https://www.ted.com/conversations/10377/is_history_an_important_subjec.html 
Haydn, T. (2011). Pupil's ideas about why they do history and why these ideas matter. In History teaching and research: Bridging the theory/practise divide. Vol. 2. Valetta, Malta.

HSRC \& EPC. (2005). Emerging voices: A report on education in South African rural communities. Cape Town, RSA: HSRC Press.

Joseph, S. (2011). What are upper secondary students saying about history? Caribbean Curriculum, 18(1), 1-26.

Kukard, K. J. (2017). The trajectory of the shifts in academic and civic identity of students in South African and English secondary school history national curriculums across two key reform moments (Unpublished master's thesis). University of Cape Town, South Africa.

Langa, M. (2018). Black African parents and school history: A narrative inquiry (Unpublished doctoral dissertation in progress). University of KwaZulu-Natal, South Africa.

Lee, P. (1998). Making sense of historical accounts. Canadian Social Studies, 32(2), 52-54.

Mackie, E. L. (2004) Attitudes to history and senses of the past among Grade 12 learners in a selection of schools in the Durban area, 2004: A pilot study (Unpublished master's thesis). University of KwaZulu-Natal, South Africa.

Mbokazi, S., \& Bhengu, T. (2008). An unexplored partnership: The influence of traditional leaders on schooling. Journal of Education,44, 1-18.

Meyer, L. J., Blignaut, D., Braz, D., \& Bunt, B. (2008). Where have all the learners gone? (A small-scale study to determine reasons for the decline in numbers of learners taking history in the FET phase). Yesterday \& Today,2, 15-29.

Ministerial Task Team. (2018). Report of the history Ministerial Task Team. Pretoria, RSA: Department of Basic Education.

Mngadi, M. (2018, January 5). KZN Education MEC satisfied with $72.87 \%$ pass rate. News24. Retrieved from https://www.news24.com/SouthAfrica/News/kzn-educationmec-satisfied-with-7287-matric-pass-rate-20180105

Moletsane, L. (2012). Repositioning educational research on rurality and rural education in South Africa: Beyond deficit paradigms. Perspectives in Education, 30(1), 1-8.

Motala, S. (2017). Introduction-Part III Achieving "free education" for the poor: A realisable goal in 2018? Journal of Education, 68, 15-29.

Patton, M. Q. (1990). Qualitative evaluation and research methods. Newbury Park, CA: SAGE. 
Rule, P., \& John, V. (2011).Your guide to case study research. Pretoria, RSA: van Schaik.

Southgate, B. (2000). Why bother with history: Ancient, modern and postmodern motivation. Hertfordshire, UK: University of Hertfordshire.

Stearns, P. N. (1998). Why study history? Retrieved from American Historical Association website https://www.historians.org/about-aha-and-membership/aha-history-andarchives/historical-archives/why-study-history-(1998)

Steen, C. (2012, April 1). Is history an important subject in school? Or should we be focussing on the future? [Online forum comment]. Retrieved from TED website: https://www.ted.com/conversations/10377/is_history_an_important_subjec.html

Subbiah, C. (2018). An investigation into how history learners view history as a subject in the secondary phase of schooling (Unpublished doctoral dissertation). University of KwaZulu-Natal, South Africa.

Taylor-Powell, E., \& Renner, M. (2003). Analysing qualitative data. University of Wisconsin-Extension. Retrieved from learningstore.uwex.edu

van der Leeuw-Roord, J. (1997). The state of history in Europe: Challenges and implications of the 'Youth and history' survey. Hamburg, DEU: Körber-Stiftung.

van Eeden, E. (2012). The youth and school history: Learning from some of the thinking of yesterday in South Africa. Yesterday \& Today, 8, 23-46.

VanSledright, B. A. (2011). History: Learning, teaching of. Retrieved from http://education.stateuniversity.com/pages/2048/history.html

Visagie, J., \& Turok, I. (2017). Rural-urban migration as a means of getting ahead. Retrieved from https://www.researchgate.net/publication/321159397_RuralUrban_Migration_as_a_Means_of_Getting_Ahead 